\title{
Extracellular Superoxide Dismutase in Human Tissues and Human Cell Lines
}

Stefan L. Marklund

Department of Clinical Chemistry, Umeà University Hospital, S-901 85, Umeà, Sweden

bstract. Extracellular-superoxide dismutase is a tetrameric copper-containing glycoprotein that previously has been demonstrated to be the major superoxide dismutase of human extracellular fluids. The occurrence of this enzyme in various human tissues that were removed from two accidental death victims and in 19 different human cultured cell lines was determined. All investigated tissues were found to contain extracellular-superoxide dismutase. There was a larger variation between tissues in the concentration of this enzyme than in $\mathrm{CuZn}$ superoxide dismutase and $\mathrm{Mn}$ superoxide dismutase. No relation could be demonstrated between the content of extracellular-superoxide dismutase and the content of the other superoxide dismutase isoenzymes in the various tissues. In uterus there was more extracellular-superoxide dismutase than Mn superoxide dismutase, but in all other tissues the content of extracellular-superoxide dismutase was lower than the content of the other isoenzymes. The concentration of extracellular-superoxide dismutase was higher in all investigated human tissues than in human plasma. 19 human cultured cell lines were found to be devoid of or to contain very little extracellular-superoxide dismutase. Most tissues contained more extracellular-superoxide dismutase than did the investigated cell lines.

\section{Introduction}

Two superoxide dismutase isoenzymes (EC 1.15.1.1.) (SOD)' have so far been described in vertebrates. CuZn SOD (1) has been demonstrated in the cytoplasm and also in the intermembrane space in mitochondria (2). Mn SOD is found in the

Received for publication 3 February 1984 and in revised form 20 June 1984.

1. Abbreviations used in this paper: Con A, concanavalin A; EC-SOD, extracellular SOD; SOD, superoxide dismutase.

J. Clin. Invest.

(c) The American Society for Clinical Investigation, Inc. 0021-9738/84/10/1398/06 \$1.00

Volume 74, October 1984, 1398-1403 matrix space in mitochondria (2) and, in primates, apparently also in the cytoplasm (3). These enzymes are found in very small amounts in extracellular fluids $(4,5)$.

The major SOD in the extracellular space in mammals is a recently described enzyme, named extracellular-SOD (ECSOD) $(4,6)$. It is a tetrameric slightly hydrophobic glycoprotein that has a molecular weight $\sim 135,000$. Upon chromatography on Heparin-Sepharose, it is divided into three fractions: A, which does not bind, $\mathrm{B}$, which elutes early in a $\mathrm{NaCl}$ gradient, and $\mathrm{C}$, which elutes late. EC-SOD contains four copper atoms and possibly also four zinc atoms (6). It has a high SOD activity and like CuZn SOD is inhibited by cyanide (6). No relation to $\mathrm{CuZn}$ SOD has been found in amino acid composition, (6) antigenic properties (7), and probably also chromosomal localization (4).

EC-SOD has also been demonstrated in some human tissues and has so far only been isolated in pure form from human lungs (6). The present paper reports a comprehensive analysis of the occurrence of EC-SOD and the other SOD isoenzymes in various human tissues and in 19 human cell lines in culture.

\section{Methods}

Concanavalin A (Con A)-Sepharose, CNBr-activated Sepharose 4B, Sepharose CL-4B, and Sephacryl S-300 were obtained from Pharmacia Fine Chemicals, Uppsala, Sweden.

Human tissues. Human tissues were obtained within $24 \mathrm{~h}$ after death from accident victims without known disease at the Department of Forensic Medicine, Umea University Hospital. The tissues were kept at $-80^{\circ} \mathrm{C}$ until preparation.

Extraction of EC-SOD. Several procedures for extraction were tested. $50 \mathrm{mM}$ sodium acetate, pH 5.5, extracted about as much ECSOD but less total protein from human lungs than the basic procedure for SOD extraction used in the laboratory (8), employing $10 \mathrm{mM}$ potassium phosphate plus $30 \mathrm{mM} \mathrm{KCl}$ (pH 7.4). $0.3 \%$ Triton X-100 in the acetate buffer reduced the yield of EC-SOD activity. Because of the heparin-affinity of EC-SOD (6), heparin and dextran sulfate $(0.4$ $\mathrm{mg} / \mathrm{ml}$ ) in the acetate buffer were tested, but were found to be without effect. Addition of the chaotropic salt $\mathrm{KBr}$ to the acetate buffer increased the yield of EC-SOD up to 2-3 times. Above $0.25 \mathrm{M} \mathrm{KBr}$, no further increase in extraction was noted. Extraction of CuZn SOD and $\mathrm{Mn}$ SOD was as effective in $50 \mathrm{mM}$ sodium acetate (pH 5.5) as in $10 \mathrm{mM}$ potassium phosphate plus $30 \mathrm{mM} \mathrm{KCl}(\mathrm{pH} \mathrm{7.4)}$ and was not influenced by $\mathrm{KBr}$. Based on the above investigation, the following procedure was adopted. The tissues were homogenized with an UltraTurrax in 10 vol of sodium acetate (pH 5.5) that contained $0.3 \mathrm{M}$ 
$\mathrm{KBr}$. The homogenates were then sonicated and finally extracted for 30 min at $4^{\circ} \mathrm{C}$. The supernatants were employed after centrifugation $(20,000 \mathrm{~g}$ for $15 \mathrm{~min})$ for the further analyses.

Human cell lines. The cells were grown in Eagle's minimal essential medium (anchorage-dependent lines) or Hanks' F-10 medium (suspension-growing lines) with $10 \%$ fetal calf serum, supplemented with benzyl penicillin and streptomycin in air that contained $5 \% \mathrm{CO}_{2}$, and saturated with $\mathrm{H}_{2} \mathrm{O}$. The cells were harvested 3-7 d after explantation in a near confluent state. The monolayer cells were scraped off in 0.15 $\mathrm{M} \mathrm{NaCl}$ with $3 \mathrm{mM}$ diethylenetriaminepentaacetic acid. Cell suspensions $\left(100-200 \times 10^{6}\right.$ cells) were washed several times in $0.15 \mathrm{M} \mathrm{NaCl}$ and then stored as pellets at $-80^{\circ} \mathrm{C}$ until assay. For assay, the cells were sonicated under cooling with ice in $1.5-3 \mathrm{ml} 50 \mathrm{mM}$ sodium acetate (pH 5.5) with $0.3 \mathrm{M} \mathrm{KBr}$. After extraction for $30 \mathrm{~min}$ at $4^{\circ} \mathrm{C}$, the homogenates were centrifuged $(20,000 \mathrm{~g}, 15 \mathrm{~min})$ and the analyses performed on the supernatants.

Separation of SOD isoenzymes with Con A-Sepharose. Unlike CuZn SOD and Mn SOD, EC-SOD binds to Con A, probably because of the presence of carbohydrate. The samples $(1-2 \mathrm{ml})$ were applied to a Con A-Sepharose column, $1 \times 1 \mathrm{~cm}$, which was equilibrated with $10 \mathrm{mM}$ potassium phosphate (pH 6.5) in $120 \mathrm{mM} \mathrm{NaCl}$. Sample aliquots of $0.5 \mathrm{ml}$ were applied with 5-min intervals to allow binding to the lectin. After $5 \mathrm{~min}, 2 \mathrm{ml}$ of the phosphate buffer was added. The eluting fluid from the homogenate and buffer additions was collected and contained the CuZn SOD and Mn SOD of the sample. Then the column was washed with $20 \mathrm{ml}$ of the phosphate buffer. The EC-SOD was then eluted with $5 \mathrm{ml}$ of $150 \mathrm{mM} \alpha$-methyl-D-mannoside in $50 \mathrm{mM}$ sodium phosphate (pH 6.5), which was added in 1-ml aliquots with 5 -min intervals. The column was regenerated with $5 \mathrm{ml}$ $0.5 \mathrm{M} \alpha$-methyl-D-mannoside followed by $20 \mathrm{ml} 10 \mathrm{mM}$ potassium phosphate (pH 6.5) in $120 \mathrm{mM} \mathrm{NaCl}$. The yield of EC-SOD from the column, tested with pure EC-SOD as well as with partially purified enzyme, was regularly $\sim 75 \%$. All figures presented are compensated for this. The results of double assays on 29 different human tissue homogenates indicated that the procedure has a variation coefficient of $10 \%$.

Analysis of SOD isoenzymes using immobilized antibodies against human CuZn SOD and human EC-SOD. Rabbits were immunized with subcutaneous injections of $100 \mu \mathrm{g}$ human $\mathrm{CuZn}$ SOD or $30 \mu \mathrm{g}$ human EC-SOD fraction A (7). The first injection of each enzyme was given in complete Freund's adjuvant and the subsequent booster injections in incomplete adjuvant. The $\mathrm{IgG}$ fractions of the rabbit antisera were isolated by the use of protein A-Sepharose. The IgG fractions were then coupled to CNBr-activated Sepharose 4B in accordance with the manufacturer's suggestions. About $5 \mathrm{mg}$ of $\mathrm{IgG}$ was coupled per milliliter of gel. The immobilized antibodies efficiently adsorbed their corresponding antigens. Anti-EC-SOD A adsorbed ECSOD fractions $A, B$, and $C$ with apparently equal capacity. No binding of EC-SOD by anti-CuZn SOD and CuZn SOD by anti-EC-SOD could be demonstrated (7).

For analysis of isoenzymes, tissue extracts were incubated overnight at $4^{\circ} \mathrm{C}$ with either (a) Sepharose 4B (sham incubation), (b) anti-CuZn SOD-Sepharose 4B, or (c) anti-CuZn SOD-Sepharose 4B plus antiEC-SOD-Sepharose 4B. After centrifugation, the SOD activity that remained in the supernatants was determined. The $\mathrm{CuZn} \mathrm{SOD}$ activity was taken as $a$ minus $b$ and the EC-SOD activity as $b$ minus $c$. The Mn SOD activity was estimated from the cyanide-resistant activity of supernatant $c$. After compensation for the slight inhibitory action of 3 $\mathrm{mM}$ cyanide on $\mathrm{Mn}$ SOD $(\sim 10 \%)$, all activity in supernatant $c$ could be accounted for as Mn SOD.
Extracts of cell lines were incubated overnight at $4 \mathrm{C}$ with either (a) Sepharose 4B or (b) anti-CuZn SOD-Sepharose 4B. After centrifugation, the SOD activity that remained in the supernatants was determined. The CuZn SOD activity was taken as $a$ minus $b$. The cyanide-sensitive activity in $b$ was assumed to represent EC-SOD activity.

Separation of SOD isoenzymes with gel chromatography. The chromatography was performed in a $1.6 \times 90-\mathrm{cm}$ column of Sephacryl S-300 at $6 \mathrm{ml} / \mathrm{h}$ with $10 \mathrm{mM}$ potassium phosphate $(\mathrm{pH} \mathrm{7.4)}$ in 0.15 $\mathrm{M} \mathrm{NaCl}$ as eluant. The tissues were extracted as described above and dialyzed against the elution buffer overnight. About $5 \mathrm{ml}$ tissue extract was applied.

SOD analysis. SOD was determined in terms of its ability to catalyze the disproportionation of $\mathrm{O}_{\bar{z}}^{\bar{z}}$ in alkaline aqueous solution. The disproportionation was directly studied in a spectrophotometer, essentially as described before (9), the difference being that both $\mathrm{CuZn}$ SOD and Mn SOD were assayed at $\mathrm{pH} 9.50$ and that $3 \mathrm{mM}$ cyanide was used for the distinction between the enzymes. $1 \mathrm{U}$ in the assay is defined as the activity that brings about a decay in $\mathrm{O}_{2}^{\overline{2}}$ concentration at a rate of $0.1 \mathrm{~s}^{-1}$ in $3 \mathrm{ml}$ buffer. It corresponds to $8.3 \mathrm{ng}$ human CuZn SOD, $8.8 \mathrm{ng}$ human EC-SOD, and $65 \mathrm{ng}$ bovine Mn SOD. The pure human manganese-containing enzyme has not been investigated with this assay, but its specific activity is probably similar to that of the bovine enzyme. The xanthine oxidase-cytochrome $C$ assay for superoxide dismutase works at physiological conditions, i.e., neutral $\mathrm{pH}$ and low $\mathrm{O}_{\bar{i}}$ concentration (1). When bovine and human enzymes are analyzed, $1 \mathrm{U}$ in the present assay corresponds to $0.024 \mathrm{U} \mathrm{CuZn}$ SOD and $0.24 \mathrm{U}$ Mn SOD, respectively, in the "xanthine oxidase" assay. The present assay is thus $\sim 10$ times more sensitive for $\mathrm{CuZn}$ SOD activity than for Mn SOD activity. As controls of the method, human hemolysates, kept at $-80^{\circ} \mathrm{C}$, were used. Aliquots were thawed and analyzed each day the method was run. A between day variation coefficient of $4 \%$ was demonstrated.

Protein analysis. For protein analysis, Coomassie Brilliant Blue G250 was employed (10). Human serum albumin was used for standardization.

\section{Results}

Human tissues. Table I presents the results of analysis of SOD isoenzymes in human tissues. The data are based on separation of tissue homogenates on Con A-Sepharose. Of the three isoenzymes, CuZn SOD showed the smallest variation in activity between the analyzed tissues. Mn SOD was a little more variable. Taking into account that the assay method is $\sim 10$ times less sensitive for Mn SOD than for CuZn SOD, it was evident that the Mn SOD activity is almost as large as the CuZn SOD activity in most tissues. In uterus there was more EC-SOD than Mn SOD, but in all other tissues the content of EC-SOD was lower than the content of the other isoenzymes. The EC-SOD activity varied more between tissues than the activity of the other isoenzymes. On the other hand, there was a rather good agreement between the content of EC-SOD in the various tissues from the two investigated individuals. There was no relation between the content of EC-SOD and the content of CuZn SOD and Mn SOD. For example, liver contains very little EC-SOD and a lot of the other isoenzymes, whereas all isoenzymes are abundant in kidney. Lung, pancreas, 
Table I. Content of SOD Isoenzymes in Human Tissues

\begin{tabular}{|c|c|c|c|c|c|c|}
\hline & EC-SOD & & CuZn SOD & & Mn SOD & \\
\hline & $U / g$ wet weight & $U / m g$ protein & $U / g$ wet weight & U/mg protein & $U / g$ wet weight & $U / m g$ protein \\
\hline Adipose tissue & B 42 & 12 & 660 & 182 & 46 & 12.6 \\
\hline \multirow[t]{2}{*}{ Adrenal gland } & A 220 & 4.0 & 26,800 & 482 & 1,370 & 24.7 \\
\hline & B 110 & 4.1 & 19,300 & 749 & 1,150 & 44.6 \\
\hline \multirow[t]{2}{*}{ Brain grey matter } & A 90 & 2.7 & 17,000 & 509 & 713 & 21.3 \\
\hline & B 36 & 0.56 & 26,700 & 414 & 1,100 & 17.0 \\
\hline \multirow[t]{2}{*}{ Brain white matter } & A 120 & 11 & 9,800 & 886 & 272 & 24.5 \\
\hline & B 130 & 8.5 & 12,300 & 778 & 299 & 19.1 \\
\hline \multirow[t]{2}{*}{ Duodenum } & A 570 & 18 & 10,000 & 311 & 358 & 11.1 \\
\hline & B 220 & 14 & 7,300 & 471 & 256 & 16.6 \\
\hline \multirow[t]{2}{*}{ Heart } & A 250 & 4.4 & 11,300 & 200 & 1,250 & 22.0 \\
\hline & B 200 & 3.8 & 15,800 & 304 & 1,480 & 28.5 \\
\hline \multirow[t]{2}{*}{ Kidney cortex } & A 240 & 2.9 & 30,200 & 369 & 1,790 & 21.9 \\
\hline & B 220 & 1.5 & 30,100 & 208 & 2,420 & 16.7 \\
\hline \multirow[t]{2}{*}{ Kidney medulla } & A 320 & 3.9 & 19,400 & 235 & 1,230 & 14.9 \\
\hline & B 470 & 6.5 & 12,300 & 170 & 890 & 12.2 \\
\hline \multirow[t]{2}{*}{ Liver } & A 80 & 0.77 & 106,900 & 1,030 & 2,260 & 21.7 \\
\hline & B $\quad 57$ & 0.89 & 63,000 & 980 & 2,300 & 35.7 \\
\hline \multirow[t]{2}{*}{ Lung } & A 790 & 11 & 7,500 & 108 & 331 & 4.7 \\
\hline & B 300 & 2.7 & 7,700 & 68 & 410 & 3.6 \\
\hline \multirow[t]{2}{*}{ Lymphatic gland } & A 760 & 12 & 7,750 & 117 & 653 & 9.9 \\
\hline & B 180 & 5.8 & 8,680 & 272 & 644 & 20.2 \\
\hline Ovary & A 420 & 8.8 & 13,200 & 274 & 147 & 3.1 \\
\hline \multirow[t]{2}{*}{ Pancreas } & A 620 & 23 & 8,630 & 319 & 778 & 28.8 \\
\hline & B 680 & 8.4 & 11,300 & 130 & 905 & 11.0 \\
\hline \multirow{2}{*}{ Skeletal muscle } & A 96 & 1.3 & 12,900 & 180 & 552 & 7.7 \\
\hline & 53 & 0.78 & 12,700 & 187 & 374 & 5.5 \\
\hline \multirow[t]{2}{*}{ Spleen } & A 68 & 0.82 & 13,300 & 160 & 285 & 3.4 \\
\hline & B 110 & 2.0 & 13,200 & 250 & 384 & 7.3 \\
\hline \multirow[t]{2}{*}{ Thyroid gland } & A 1,500 & 23 & 10,700 & 165 & 276 & 4.3 \\
\hline & B 920 & 7.3 & 14,500 & 115 & 276 & 2.2 \\
\hline \multirow[t]{2}{*}{ Uterus } & A 1,800 & 69 & 8,100 & 320 & 159 & 6.3 \\
\hline & X 720 & 41 & 6,850 & 244 & 168 & 9.4 \\
\hline
\end{tabular}

Tissues from two healthy individuals were investigated, A a woman and B a man. X, uterus from a second woman. The EC-SOD content was determined by means of the Con A-Sepharose procedure.

thyroid gland, and uterus all possess comparatively much ECSOD but not particularly much of the other isoenzymes.

Human cell lines in culture. Table II presents the results of analysis of SOD isoenzymes in various human cell lines. The contents of CuZu SOD and Mn SOD are similar to those presented before (8). The content of EC-SOD was very low in all investigated cell lines, and lower than that found in most tissues (Table I).

Analysis of SOD isoenzymes using immobilized antibodies against human CUZn SOD and human EC-SOD. The Con ASepharose method is based on the assumption that $\mathrm{CuZn}$ SOD and Mn SOD represent all SOD activity without Con A 
Table II. Content of EC-SOD in Cultured Human Cell Lines

\begin{tabular}{|c|c|c|c|}
\hline Cell line & $\begin{array}{l}\text { Total SOD } \\
\text { activity }\end{array}$ & $\begin{array}{l}\text { EC-SOD (SOD } \\
\text { with Con A affinity) }\end{array}$ & $\begin{array}{l}\text { EC-SOD } \\
\text { (determine } \\
\text { with anti- } \\
\text { CuZn-SOD }\end{array}$ \\
\hline & $U / m g$ protein & U/mg protein & $U / m g$ prote \\
\hline \multicolumn{4}{|l|}{ Anchorage dependent } \\
\hline \multicolumn{4}{|l|}{$\begin{array}{c}\text { Embryonal lung } \\
\text { fibroblasts }\end{array}$} \\
\hline HEL A & 140 & 0.99 & 0 \\
\hline \multicolumn{2}{|l|}{ Endothelial cells, } & 1.3 & ND \\
\hline Malignant melanoma & 208 & 0.03 & ND \\
\hline \multicolumn{4}{|l|}{ Malignant glioma } \\
\hline $251 \mathrm{MG}$ & 209 & 0.11 & 1.5 \\
\hline 63 MG & 211 & 0.24 & 0.62 \\
\hline \multicolumn{4}{|l|}{$\begin{array}{l}\text { Cervical } \\
\quad \text { adenocarcinoma }\end{array}$} \\
\hline HeLa & 133 & 0.24 & 0.32 \\
\hline \multicolumn{4}{|l|}{$\begin{array}{l}\text { Malignant } \\
\text { mesothelioma }\end{array}$} \\
\hline P 27 & 343 & 0.1 & ND \\
\hline P 31 & 220 & 0.26 & 1.3 \\
\hline \multicolumn{4}{|l|}{$\begin{array}{l}\text { Renal carcinoma } \\
\text { epithelial } \\
\text { aneuploid }\end{array}$} \\
\hline $\mathrm{HCV}$ & 128 & 0.41 & 0.64 \\
\hline \multicolumn{4}{|l|}{ Suspension growing } \\
\hline \multicolumn{4}{|l|}{$\begin{array}{l}\text { Lymphoblastoid } \\
\text { diploid B cells }\end{array}$} \\
\hline $\mathrm{LiA}$ & 197 & 0.24 & 1.0 \\
\hline \multicolumn{4}{|l|}{$\begin{array}{l}\text { Myeloma } \\
\text { plasmablasts }\end{array}$} \\
\hline RPMI & 219 & 0.22 & 0.69 \\
\hline \multicolumn{4}{|l|}{$\begin{array}{l}\text { Burkitts lymphoma, } \\
\text { aneuploid B } \\
\text { lymphoblasts }\end{array}$} \\
\hline Namalwa & 88 & 0.49 & ND \\
\hline P3HRI & 119 & 0 & ND \\
\hline MN 60 & 249 & 0.09 & 3.3 \\
\hline \multicolumn{4}{|l|}{$\begin{array}{l}\text { Lymphocytic } \\
\text { leukemia T } \\
\text { lymphoblast }\end{array}$} \\
\hline Jurkat & 194 & 0 & ND \\
\hline \multicolumn{4}{|l|}{$\begin{array}{l}\text { Histiocytic } \\
\text { lymphoma }\end{array}$} \\
\hline U 937 & 121 & 0 & ND \\
\hline \multicolumn{4}{|l|}{$\begin{array}{l}\text { Myeloid leukemia } \\
\text { promyelocytes }\end{array}$} \\
\hline HL 60 & 230 & 0.69 & 3.2 \\
\hline $\begin{array}{l}\text { KG } 1 \text { myeloblasts } \\
\text { K } 562-4 \text { blastic }\end{array}$ & 190 & 0.82 & 0.67 \\
\hline crisis & 290 & 0.67 & 4.4 \\
\hline
\end{tabular}

The EC-SOD contents of the cell extracts were analyzed with two different procedures, using Con A-Sepharose or anti-human CuZn SOD. ND, not determined.

affinity, and that activity with Con A-Sepharose affinity is ECSOD. For comparison, 12 different human tissue homogenates were also analyzed with a procedure based on adsorption to immobilized antibodies against $\mathrm{CuZn}$ SOD and EC-SOD (Table III). As seen, there is a relatively good agreement between the two procedures. The Con A-Sepharose data are in general a little lower.

The EC-SOD content of cell line extracts were determined with a slightly different procedure that employed immobilized $\mathrm{CuZn}$ SOD (Table II). The results confirm the very low figures for EC-SOD content that were obtained with the Con ASepharose procedure but are in poorer agreement than above. With this method, however, the EC-SOD activity is taken as the (small) difference in SOD activity of antibody-treated samples in the presence and absence of $3 \mathrm{mM}$ cyanide.

Fractions that were obtained upon separation of tissue extracts on Con A-Sepharose were also investigated with the immobilized antibodies. It was found that all SOD activity of $\alpha$-methyl-D-mannoside-eluted fractions from six different tissue extracts could be adsorbed to anti-EC-SOD. No significant adsorption to anti-CuZn-SOD could be demonstrated. This showed that all SOD activity with Con A-affinity is EC-SOD.

In the fractions that eluted without binding to Con $A$, some SOD activity with affinity for anti-EC-SOD could be demonstrated. In fractions from seven different tissue extracts a mean of $0.8 \%$ of the activity bound to immobilized antiEC-SOD. These extracts had a mean EC-SOD activity of $6.1 \%$ as estimated with the antibody-method. The results indicated that some underestimation (mean $\sim 10 \%$ ) results from the Con A-procedure due to incomplete attachment of EC-SOD during the chromatography. The findings were in agreement with the results of Table III, which, in general, show slightly lower figures for the Con A procedure.

Table III. Comparison of EC-SOD Determined with Con A Sepharose and with Antibodies against $\mathrm{CuZn}$ $S O D$ and EC-SOD Immobilized on Sepharose

\begin{tabular}{lll}
\hline & $\begin{array}{l}\text { EC-SOD } \\
\text { determined with } \\
\text { Con A-Sepharose }\end{array}$ & $\begin{array}{l}\text { EC-SOD determined with } \\
\text { antibodies against CuZn } \\
\text { SOD and EC-SOD }\end{array}$ \\
\hline Brain, white matter & $\%$ & $\%$ \\
Brain, grey matter & 0.13 & 0.30 \\
Duodenum & 0.5 & 0.5 \\
Heart muscle & 4.7 & 4.6 \\
Kidney, cortex & 1.9 & 2.9 \\
Liver & 0.9 & 1.8 \\
Lung & 0.1 & 0.3 \\
Lymphatic gland & 4.3 & 5.7 \\
Pancreas & 9.3 & 11.1 \\
Skeletal muscle & 5.8 & 7.3 \\
Spleen & 0.8 & 0.8 \\
Thyroid gland & 0.4 & 0.4 \\
& 10.7 & 11.4
\end{tabular}

EC-SOD was determined with the two procedures as described in Methods. The results are presented as percentage of total SOD activity of the homogenates. 
Analysis with gel chromatography. The third method for EC-SOD estimation is based on the larger molecular weight of EC-SOD compared with Mn SOD and CuZn SOD. Fig. I shows gel chromatography of a human uterus homogenate as an example. The position of the first peak of SOD activity corresponds to the molecular weight of EC-SOD, whereas the second larger peak has a molecular weight of $\sim 30,000$ and should be CuZn SOD. The cyanide-resistant peak probably represents Mn SOD. The area of the high molecular weight peak corresponds to $\sim 21.4 \%$ of the SOD activity in the chromatogram. This was in good agreement with the estimate of EC-SOD using Con A-Sepharose, which was found to be $19.4 \%$. Several other tissue homogenates were analyzed in the same way. The gel chromatography estimates vs. Con ASepharose estimates were: heart, 0.6 vs. $1.9 \%$, brain, 0.4 vs. $1.3 \%$, and lung, 6.5 vs. $8.8 \%$. The agreement was fairly good and the lower figures for the gel chromatography estimates might be explained by the tendency of EC-SOD fraction A to dissociate into subunits (6). Such an effect would tend to decrease the size of the high molecular weight EC-SOD peak and lead to some degree of underestimation.

\section{Discussion}

EC-SOD, which was previously shown to be the major SOD in the extracellular space (4), was demonstrated in all investigated tissues. The enzyme was not isolated from the tissues and positively identified, but three independent methods that employed different properties of the EC-SOD molecule resulted in very similar estimates. Small amounts of EC-SOD could also be demonstrated in some of the investigated cultured cell lines. The investigated cell lines represent far from a complete

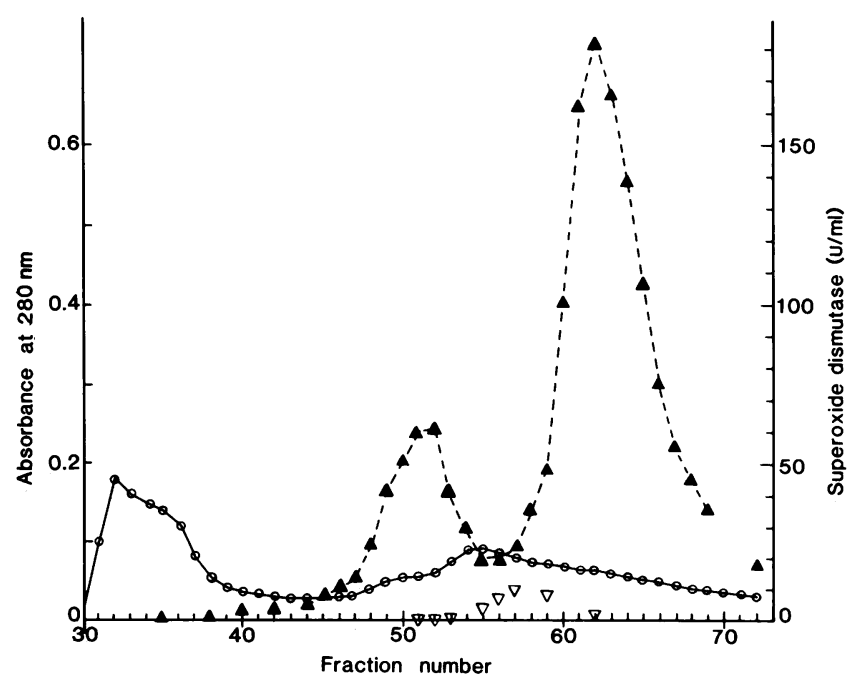

Figure 1. Gel chromatography of a human uterus homogenate on Sephacryl S-300. The chromatography was performed as described in Methods. Absorbance at $\mathbf{2 8 0} \mathrm{nm}(0)$, total SOD activity ( $\triangle$ ), and SOD activity in the presence of $3 \mathrm{mM}$ cyanide $(\nabla)$. survey of different human cell types, but the results serve to indicate that a high content of EC-SOD is, unlike the case of CuZn SOD and Mn SOD (8), not a widespread property among different human cell types. The content of EC-SOD varied much between tissues. This fact, together with the findings in the cell lines, indicates that tissue EC-SOD is not evenly distributed among the cells in the tissues but rather localized to some specific cell types or other specific locations. Although EC-SOD was the least predominant isoenzyme in the tissues as a whole, its importance may be considerable in such specific locations.

The physiological role(s) of EC-SOD are still obscure. There are several indications that one role is to be a plasma protein and hence a protector in the extracellular space. It is the major SOD in human extracellular fluids (4). Although the present data show that the content of EC-SOD per gram tissue (Table I) is $\sim 10$ times higher than per milliliter plasma (4), the ratios for CuZn SOD $(\sim 15,000$, Table I and reference 4) and Mn SOD (several hundred, Table I and references 4 and 5) are much higher. The presence of the latter enzymes in plasma are, in all probability, the result of passive leakage from the intracellular space. The plasma content of EC-SOD has previously been analyzed in different mammalian species. Although large variations were revealed between species, there was a remarkably small variation among individuals within the various species (4). Unlike most intracellular proteins and like most plasma proteins, EC-SOD is a glycoprotein. The hydrophobicity of EC-SOD and its affinity for heparin might indicate affinity for membrane lipids and heparan sulfate on cell surfaces. Possibly, part of the tissue EC-SOD is bound in that way.

As to the site of synthesis of plasma EC-SOD, little can be deduced from the present data. Liver, an important source of plasma protein, is a less likely candidate because of its very low EC-SOD content (Table I). Neither did endothelial cells, which also synthesize many types of plasma proteins, contain much EC-SOD. However, that does not exclude all types of endothelial cells. The present cells were from large vessels in umbilical cords, and endothelial cells from different sources are known to be of quite different character. Xanthine oxidase, an enzyme of great interest in the present context, can, for example, only be demonstrated in capillary endothelium and not in cells from larger vessels (11).

The demonstration of a third SOD isoenzyme, EC-SOD, in tissue extracts complicates selective SOD assay. Previously, cyanide has been employed for the distinction between $\mathrm{CuZn}$ SOD and Mn SOD. To that practice should be added procedures that allow distinction between the cyanide-sensitive isoenzymes EC-SOD and CuZn SOD.

\section{Acknowledgments}

The skillful technical assistance of Ms Agneta Öberg and Mr Thord Johansson is gratefully acknowledged. Cell lines were kindly donated by Drs. Christer Busch, Erik Lundgren, and Göran Roos. 
The study was supported by the Swedish Medical Research Council grant 04761, the Swedish Cancer Society grant 1784, the Lions Research Foundation, Department of Oncology, Umea, University Hospital, and the Foundation for Medical Research, Umea University.

\section{References}

1. McCord, J. M., and I. Fridovich. 1969. Superoxide dismutase, an enzymic function for erythrocuprein. J. Biol. Chem. 244:60496055.

2. Weisiger, R. A., and I. Fridovich. 1973. Mitochondrial superoxide dismutase. Site of synthesis and intramitochondrial localisation. $J$. Biol. Chem. 248:4793-4796.

3. McCord, J. M., J. A. Boyle, E. D. Day, L. Rizzolo, and M. L. Salin. 1977. A manganese-containing superoxide dismutase from human liver. In Superoxide and Superoxide Dismutases. A. M. Michelson, J. M. McCord, and I. Fridovich, editors. Academic Press, Inc., New York. 129-138.

4. Marklund, S. L., E. Holme, and L. Hellner. 1982. Superoxide dismutase in extracellular fluids. Clin. Chim. Acta. 126:41-51.

5. Baret, A., M. A. Baeteman, J. F. Mattei, P. Michel, B. Broussoulle, and F. Giraud. 1981. Immunoreactive CuSOD and MnSOD in the circulating blood cells from normal and trisomi 21 cells. Biochem. Biophys. Res. Commun. 98:1035-1041.

6. Marklund, S. L. 1982. Human copper-containing superoxide dismutase of high molecular weight. Proc. Natl. Acad. Sci. USA. 79:7634-7638.

7. Marklund, S. L. 1984. Properties of extracellular superoxide dismutase from human lung. Biochem. J. 220:269-272.

8. Marklund, S. L., N. G. Westman, E. Lundgren, and G. Roos. 1982. Copper and zinc-containing superoxide dismutase, manganesecontaining superoxide dismutase, catalase and glutathione peroxidase in normal and neoplastic human cell lines and normal human tissues. Cancer Res. 42:1955-1961.

9. Marklund, S. L. 1976. Spectrophotometric study of spontaneous disproportionation of superoxide anion radical and sensitive direct assay for superoxide dismutase. J. Biol. Chem. 251:7504-7507.

10. Bradford, M. M. 1976. A rapid and sensitive method for the quantitation of protein utilizing the principle of protein-dye binding. Anal. Biochem. 72:248-254.

11. Jarasch, E. D., C. Grund, G. Bruder, H. W. Heid, T. W. Keenan, and W. W. Franke. 1981. Localization of xanthine oxidase in mammary-gland epithelium and capillary epithelium. Cell. 25:6782. 